\section{Rising Incidence of Caesarean Section Rate - A Dilemma for Modern Obstetrics}

\section{Zahra Safdar* and Sumera Zaib}

Department of obstetrics and Gynaecology, Lahore General Hospital, Lahore, Pakistan

\section{Summary}

Objectives: To study the rate of caesarean sections (indications, ratio in emergency and elective caesarean sections) the percentage of vaginal birth after caesarean sections and instrumental deliveries.

Methods: This retrospective study was conducted over a period of one year from 1st January 2018 to 31st December 2018 at the Department of obstetrics and gynaecology, unit 2, Lahore general hospital, Lahore. The data of obstetrical patients who got admitted in the unit and were delivered either vaginally or through abdominal route during the defined study period was recorded and a statistical analysis of various parameters namely the caesarean section rates, its indications, the ratio of emergency and elective caesarean sections, the rate of Vaginal Births after Caesarean Section (VBACS) and instrumental deliveries was done.

Results: The total numbers of obstetrical patients admitted over the study period were 18183 . Out of which total deliveries were 6602, vaginal births were 3699 and caesarean sections were 2765 . The overall caesarean section rate was $41.88 \%$, elective sections were $473(17.1 \%)$ and emergency sections were $2292(82.89 \%)$. The vaginal births were $3699(56.02 \%)$, VBACS were $98(2.6 \%)$, instrumental deliveries like forcep deliveries were $31(0.8 \%)$ and ventouse deliveries were $47(1.2 \%)$. There were $38(1.02 \%)$ twin deliveries and $59(1.5 \%)$ assisted breech deliveries. The caesarean sections done electively as well as in emergency with different indications were calculated individually.

Conclusion: The rising incidence of caesarean section is most pressing fact of the decade in modern obstetrics. The detailed audit of the caesarean sections done over a year in a tertiary care hospital showed a large number of sections done due to fetal distress. The confirmation of its diagnosis to prevent unnecessary surgeries is

*Corresponding author: Zahra Safdar, Department of obstetrics and Gynaecology, Lahore General Hospital, Lahore, Pakistan, Tel: +92 3136777022 ; E-mail: zsafdar2@gmail.com

Citation: Safdar Z, Zaib S (2020) Rising Incidence of Caesarean Section Rate A Dilemma for Modern Obstetrics. J Reprod Med Gynecol Obstet 5: 059.

Received: September 25, 2020; Accepted: October 13, 2020; Published: October 20, 2020

Copyright: (c) 2020 Safdar Z, et al. This is an open-access article distributed under the terms of the Creative Commons Attribution License, which permits unrestricted use, distribution, and reproduction in any medium, provided the original author and source are credited. pivotal. The previous scars and indications related to them are the most important component in the study so concluding this study to take steps in prevention of primary caesarean section is foremost.

Keywords: Caesarean section; Indications; Statistical analysis; Vaginal births; Tertiary care hospital

\section{Introduction}

Caesarean section is the most commonly performed surgery all over. The World Health Organization (WHO) has an acceptable caesarean section rate of $5-15 \%$ and those countries in which its rate is above $15 \%$, it is considered to be unnecessary use of surgical delivery while countries have caesarean section rate less than $5 \%$ are related to lack of access to medical technology. With the advancement and availability of anaesthesia and surgical facilities, there has been an increasing trend of caesarean delivery [1]. Health systems around the world have improved over last 30 years leading to innovations in fetomaternal monitoring during labour and delivery. Early interventions have been related to rising trends of surgical delivery.

Availability of surgical option to more and more patients has changed the perception of a caesarean section. Women opting for caesarean section by choice have become common. Increasing age of mothers in their first pregnancy, educational and financial status of mothers, fear of labour pains and shortening of time spent in labour are major contributing factors towards opting for elective caesarean section. Good experience of a caesarean section is a persuading factor for mothers to opt caesarean delivery again. The safety of anaesthesia and surgery itself has changed the choice of mode of delivery among obstetricians as well. The social pressure of a perfect baby to be born, on mother and obstetrician is imparting a deep effect on obstetrical choices in recent history. The perception of caesarean being safer than vaginal birth is a major contributor to the drastic rise in caesarean section rate all around the world. However, this notion has proved to be incorrect and caesarean delivery has 8 times more mortality and 8 - 12 times morbidity as compared to vaginal birth [2].

The concept of safe and healthy baby after caesarean section has also been challenged. The fetal risks associated with caesarean section are also higher as compared to vaginal birth. The risks of acute respiratory distress syndrome are higher in those born via elective caesarean section [3].

According to $\mathrm{WHO}$, the caesarean section rates have risen in all parts of the world (Figure 1). Recent studies show caesarean section rate of $18.6 \%$ - almost 1 in 5 women is undergoing caesarean section. The comparison of statistics of 1990 to 2014 show a global rise in caesarean section rate by $12.4 \%$. Dominion Republic, Brazil, Egypt and Turkey have a caesarean section rate of more than $50 \%$.

\section{Materials and Methods}

A retrospective study was carried out for a period of one year from January $1^{\text {st }} 2019$ to December $31^{\text {st }} 2019$ at the Department of 
Obstetrics and Gynaecology, Lahore General Hospital, Lahore. The data of obstetrical patients admitted in the department was analysed by SPSS 25 according to their route of delivery, caesarean section rate was calculated, rates of elective and emergency caesareans was calculated, indications of caesarean section were analysed, ratio of Vaginal Birth after Caesarean Section (VBAC) and instrumental deliveries were also calculated. The data was compared to the data from the same department in last 5years as well.

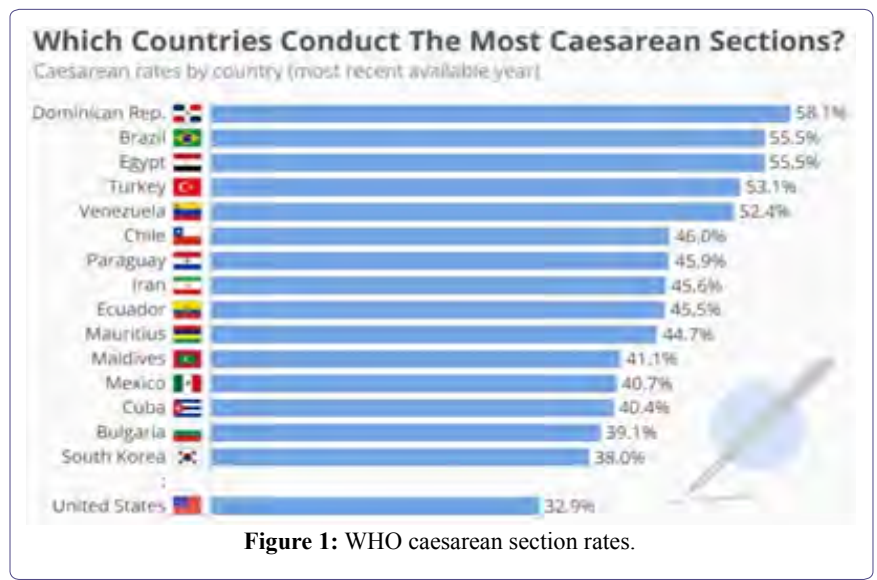

\section{Results}

The total number of antenatal patients who visited antenatal clinics during the study period was 64,578 . The total obstetrical patients admitted in the unit were 18,183 . Out of the admitted patients, 6602 were delivered. There were 3699 vaginal births and 2765 were caesarean sections. The caesarean section rate was found to be $41.88 \%$. There were $473(17.1 \%)$ elective caesarean sections and Caesarean sections were 2293 (82.89\%). The vaginal deliveries were $3699(56.02 \%)$. Out of vaginal births (Figure 2), vaginal births after caesarean section were 98 (2.6\%), instrumental deliveries 78 (2\%), twin deliveries $38(1.02 \%)$ and assisted breech deliveries 59 $(1.5 \%)$. Out of instrumental deliveries, forcep deliveries were 31 $(0.8 \%)$ while ventouse deliveries were $47(1.2 \%)$.

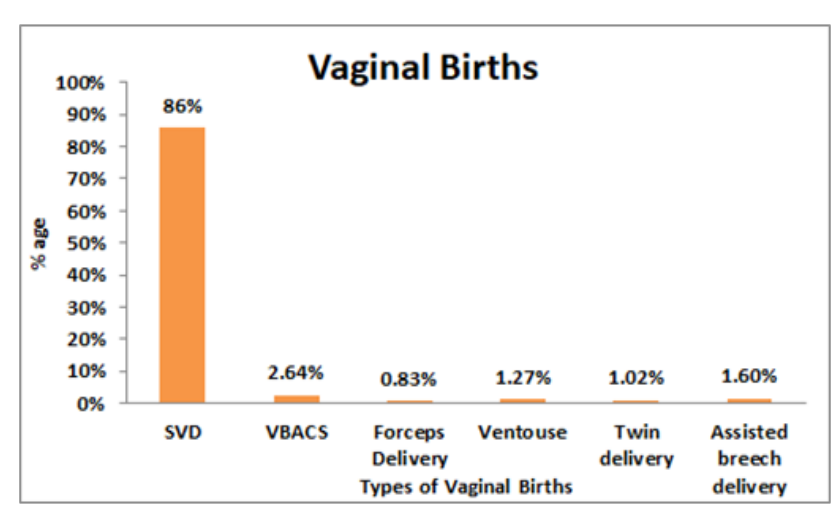

Figure 2: Types of vaginal births.

Emergency caesarean sections (Figure 3) carried out due to fetal distress were 549 (23.95\%), failed progress $266(11.6 \%)$, antepartum haemorrhage $85(3.70 \%)$, mal presentations $208(9.07 \%)$, multiple pregnancy $106(4.62 \%)$, failed induction $215(9.38 \%)$, previous caesarean with medical disorder $172(7.50 \%)$, previous caesarean with short interval $162(7.06 \%)$ and previous caesarean section in labour were $535(23.34 \%)$. The indications of elective caesarean sections ere previous 2 caesarean births $175(36.9 \%)$, previous 3 caesarean births were $107(22.6 \%)$, previous 4 caesarean sections were $62(13.1 \%)$, previous 5 caesarean sections were $33(6.97 \%)$, previous 6 caesarean sections were $16(3.38 \%)$, placenta previa was $39(8.24 \%)$ while those with already diagnosed with placenta accrete spectrum/ Morbidly Adherent Placenta (MAP) were 41 (8.24\%). The data of 2019 was compared with the statistics of last five years in terms of caesarean section rate with rate of caesarean section in 2014 to 2018 being $28.6 \%, 30.9 \%, 34.3 \%, 37.5 \%$ and $41.2 \%$ respectively, showing a steady rise over last five years as comparison with 2019 being highest of them all $41.8 \%$.

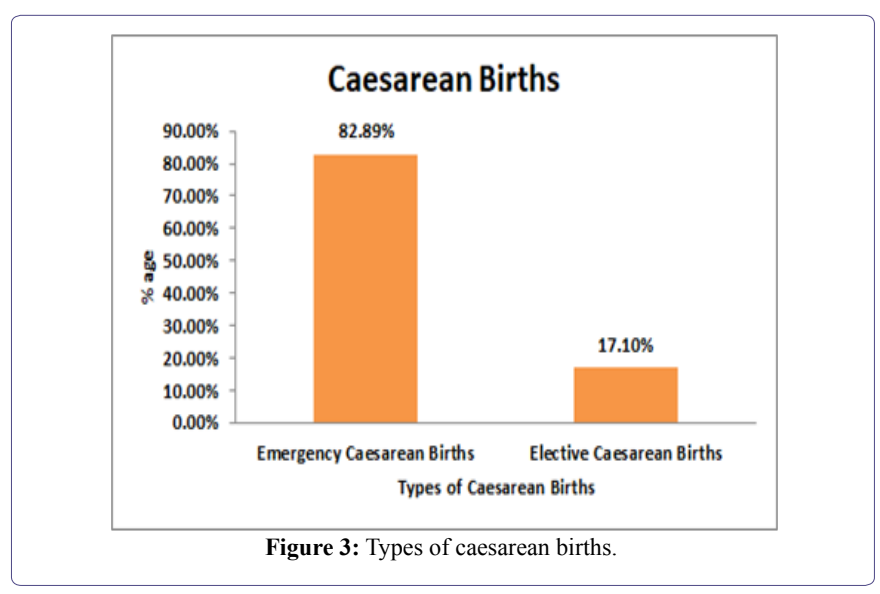

\section{Discussion}

The caesarean section rate has been at rise internationally, but previously according to WHO, Pakistan was one of the countries with lowest caesarean section rates along with Afghanistan. In recent years, the obstetrical care in urban Pakistan has improved hence, increasing caesarean section rates [4]. Many countries in south Asian region are following the same international trend and obstetrical practice has changed over the last few decades. The statistical analysis done in Pakistan has shown the similar trend of rise in 2000s [2,5]. In neighbouring South Asian countries, like India, Nepal and Bangladesh statistics show a rise in trends of caesarean section [6,7]. In our study, the caesarean section rate is $41.8 \%$ which is high but many countries have a higher rate of caesarean section than this, world-wide the caesarean section rate has been studied and divided into regions according to their wealth and development showing a relatively low rate in our region [8]. The emergency caesarean sections are a big part of total caesarean sections, $82.89 \%$ were emergency surgeries in our study. This is a huge burden on emergency services both financially and physically. Many studies carried out all around the world advocate this rise in caesarean sections in emergency [9]. The most common indication for emergency caesarean sections in our study was fetal distress (23.95\%). The diagnosis of fetal distress is very controversial, the role of cardiotocogram is limited and invasive testing is important in decision making but in our setup fetal scalp sampling is not available. Hence quarter of caesarean sections done on suspicion of fetal distress. The other important indication is previous caesarean in labour $(23.34 \%)$. The role of antenatal counselling and birth spacing is noteworthy in prevention of short inter-pregnancy 
intervals with antenatal and postpartum counselling of couples and proper counselling is important to tell the patients to get elective rather emergency caesarean if already has a known indication. Attitude of pregnant women needs to be changed towards their place of delivery. Failed progress (11.6\%) of labour is another important indication which can be decreased with one-on-one monitoring and conscious efforts to prevent failed progress. Failed induction (9.38\%) can also be prevented by proper patient selection, priming of cervix prior to medical induction and induction of patients with favourable cervix. As elective caesarean sections were $17.1 \%$ of total caesarean sections, more than $80 \%$ of the elective caesarean sections were due to previous caesarean section. The caesarean sections carried out due to placenta previa were $8.24 \%$ and those due to morbidly adherent placenta were $8.66 \%$. The caesarean sections due to placenta previa and morbidly adherent placenta [10] has also increased over the last decade due rising caesarean section rate. The incidence of morbidly adherent placenta has also impacted badly on obstetrics of our population and burdened our setups with complicated surgeries.

Out of 3699 vaginal births, only 98 (2.6\%) births were Vaginal Births after Caesarean Sections (VBACs). This study shows the vaginal births carried out after caesarean section were very low and trial of labour was not given to patients hence rising caesarean section rate (Figures 4 and 5). Studies advocate the role of proper antenatal counselling about birth spacing, counselling the couple about safety of VBACs if carried out in proper hands and role of proper assessment in labour is important $[11,12]$. The number of assisted breech deliveries was $59(1.6 \%)$. This shows the inclination of obstetricians towards caesarean as a safe option for delivery of breech babies. Although many international studies, advocate vaginal delivery of suitable patients with breech presentation in both term and pre term patients $[13,14]$. The training and teaching of young obstetricians in assisted breech delivery can play a role in reducing primary caesarean section rate. Another aspect of reducing caesarean sections due to breech presentation is education of women in late antenatal period about External Cephalic Version (ECV) and implementation of ECV as an effective method of reduced of caesarean sections due to breech presentation [15].

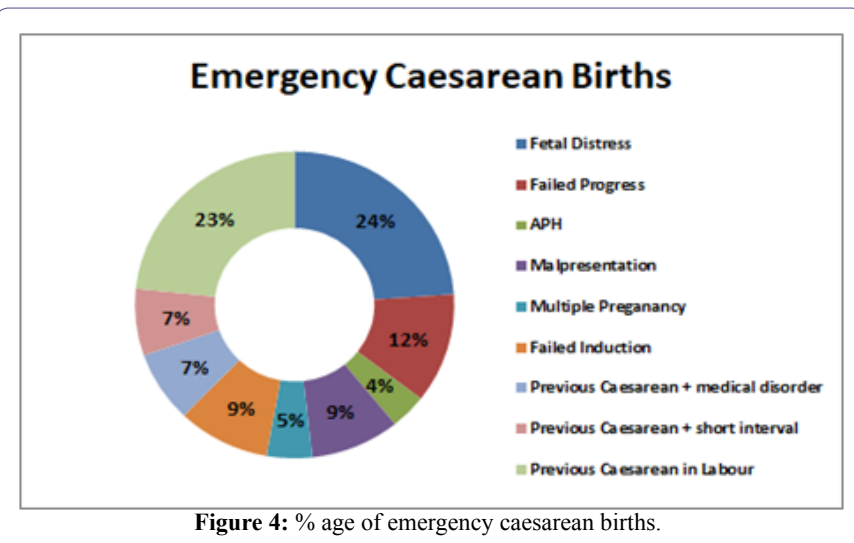

Instrumental deliveries were only $78(2.1 \%)$ according to our study. The assisted vaginal deliveries in USA are 1 in 20 , estimated to be $5 \%$ of total deliveries [16]. The statistics show a large difference between our data and developed world, who have invested in training and skill development of the birth attendants. The art of instrumental deliveries is dying and becoming obsolete due to lack of adequate knowledge and skill of the obstetricians [17].

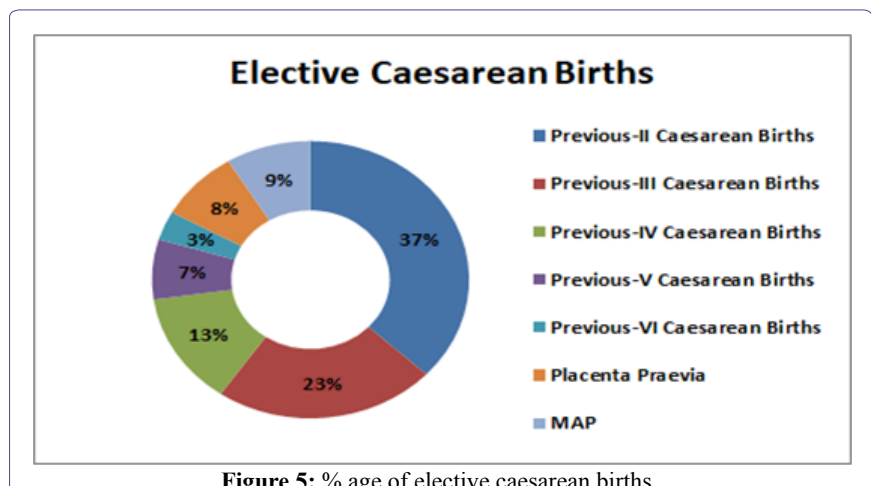

The statistical analysis of last five years of our set up shows a steady rise in caesarean section from $28.6 \%$ in $2014,30.9 \%$ in 2015 , $34.3 \%$ in $2016,37.5 \%$ in $2017,41.2 \%$ in 2018 and $41.8 \%$ in 2019 (Figure 6). There was sharp rise between 2017 and 2018.Sub division of emergency and elective caesarean sections in 2017 indicates that elective caesareans were $81.7 \%$ and emergency caesarean sections were $18.3 \%$. Comparison of caesarean section with our neighbouring countries like Bangladesh, shows an increase in last 10years [18]. Worldwide, last decade has shown a rapid rise in delivery via caesarean section more than $20 \%$ in both developed and under developed nations. But in our society, the rising caesarean section rate is alarming as it has financial as well as physical constraints on our health system. Rising trend of caesarean sections in our country will have a long- term effect on our generation not only in obstetric terms but later in their gynaecologic implications as well. Repeated surgeries will have adverse effects on the complications in future pregnancies as well as other gynaecological and non - gynaecological surgeries.

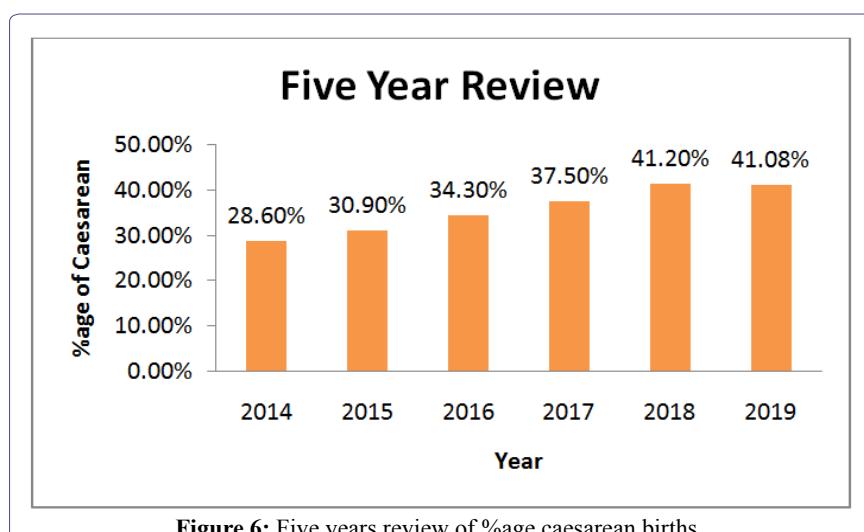

Figure 6: Five years review of \%age caesarean births.

\section{Conclusion}

The rising caesarean section rate in our society depicts change in our obstetric approach. The role of prevention of primary caesarean section is pivotal. Most of the caesareans are being carried out in emergency with relatively increased complications which can be prevented by interventional fetal monitoring like fetal scalp sampling and $\mathrm{pH}$ monitoring, also one-on-one monitoring approach 
can improve vaginal delivery rates in our setup. The emphasis on antenatal and post natal counselling about contraception and birth spacing can reduce the rate of repeat caesarean sections in emergency and elective lists. Trial of labour after caesarean section should be carried out to reduce caesarean section rates and increasing VBAC rate can be done by training of the obstetricians and birth attendants. All patients with breech presentation do not require caesarean delivery. External cephalic version and term or pre term breech delivery should be opted in suitable patients. Use of instrumental delivery in suitable patients should be opted. Training and teaching of birth attendants and obstetricians in dying arts of instrumental delivery and use of safe options in instrumental delivery like ventouse and kiwi cup should be opted to prevent feto- maternal complications. Audit and surveillance of caesarean sections should be carried out annually to identify the preventable causes of caesarean sections.

\section{References}

1. Encyclopaedia Britannica (2009) Leaf-nosed bat. Encyclopædia Britannica, United Kingdom.

2. Villar J, Valladares E, Wojdyla D, Zavaleta N, Carroli G, et al. (2006) Caesarean delivery rates and pregnancy outcomes: The 2005 WHO global survey on maternal and perinatal health in Latin America. Lancet 367: 1819-1829.

3. Gould JB, Danielson B, Korst LM, Phibbs R, Chance K, et al. (2004) Cesarean delivery rates and neonatal morbidity in a low-risk population. $\mathrm{Ob}-$ stet Gynecol 104: 11-19.

4. Khan A, Ghani T, Rahim A, Rahman MM (2014) Changing trends in incidence and indications of caesarean section. Mymensingh Med J 23: 52-55.

5. Hafeez M, Yasin A, Badar N, Pasha MI, Akram N, et al. (2014) Prevalence and indications of caesarean section in a teaching hospital. Journal International Medical Sciences Academy 27: 15-16.

6. Rahman MM, Haider MR, Moinuddin Md, Rahman AE, Ahmed S, et al. (2018) Determinants of caesarean section in Bangladesh: Cross-sectional analysis of Bangladesh Demographic and Health Survey 2014 Data. PloS one 13: 0202879 .
7. Desai G, Anand A, Modi D, Shah S, Shah K, et al. (2017) Rates, indications, and outcomes of caesarean section deliveries: A comparison of tribal and non-tribal women in Gujarat, India. PLoS One 12: 0189260.

8. Betrán AP, Ye J, Moller AB, Zhang J, Gülmezoglu AM, et al. (2016) The Increasing Trend in Caesarean Section Rates: Global, Regional and National Estimates: 1990-2014. PloS One 11: 0148343.

9. Menacker F, Declercq E, Macdorman MF (2006) Cesarean delivery: Background, trends, and epidemiology. Semin Perinatol 30: 235-241.

10. Safdar Z, Fatima S (2020) The Professional Medical Journal 27: 1795 1798.

11. Guo N, Bai RM, Qu PF, Huang P, He YP, et al. (2019) [Influencing factors and antenatal assessment of the vaginal birth after cesarean section]. Zhonghua Fu Chan Ke Za Zhi 54: 369-374.

12. Qu ZQ, Ma RM, Xiao X, Tian YQ, Li BL, et al. (2016) [The outcome of trial of labor after cesarean section]. Zhonghua fu Chan ke za zhi 51: 748-753.

13. Breton A, Gueudry P, Branger B, Le Baccon F-A, Thubert T, et al. (2018) Comparison of obstetric prognosis of attempts of breech delivery: Spontaneous labor versus induced labor. Gynecol Obstet Fertil Senol 46: 632638.

14. Toijonen AE, Heinonen ST, Gissler MVM, Macharey G (2020) A comparison of risk factors for breech presentation in preterm and term labor: A nationwide, population-based case-control study. Arch Gynecol Obstet 301: 393-403.

15. Koutrouvelis GO (2019) Role of External Cephalic Version in Reducing the Cesarean Delivery Rate. Obstet Gynecol 133: 855-856.

16. Ali UA, Norwitz ER (2009) Vacuum-assisted vaginal delivery. Rev Obstet Gynecol 2: 5-17.

17. Bailey P, de Bocaletti E, Barrios G, de Cross Y (2005) Monitoring utilization and need for obstetric care in the highlands of Guatemala. International journal of gynaecology and obstetrics: the official organ of the International Federation of Gynaecology and Obstetrics 89:209-217.

18. Hasan F, Alam MM, Hossain MG (2019) BMC Pregnancy and Childbirth 19: 433. 


\section{di \\ Hetario}

Advances In Industrial Biotechnology | ISSN: 2639-5665

Advances In Microbiology Research | ISSN: 2689-694X

Archives Of Surgery And Surgical Education | ISSN: 2689-3126

Archives Of Urology

Archives Of Zoological Studies | ISSN: 2640-7779

Current Trends Medical And Biological Engineering

International Journal Of Case Reports And Therapeutic Studies | ISSN: 2689-310X

Journal Of Addiction \& Addictive Disorders | ISSN: 2578-7276

Journal Of Agronomy \& Agricultural Science | ISSN: 2689-8292

Journal Of AIDS Clinical Research \& STDs | ISSN: 2572-7370

Journal Of Alcoholism Drug Abuse \& Substance Dependence | ISSN: 2572-9594

Journal Of Allergy Disorders \& Therapy | ISSN: 2470-749X

Journal Of Alternative Complementary \& Integrative Medicine | ISSN: 2470-7562

Journal Of Alzheimers \& Neurodegenerative Diseases | ISSN: 2572-9608

Journal Of Anesthesia \& Clinical Care | ISSN: 2378-8879

Journal Of Angiology \& Vascular Surgery | ISSN: 2572-7397

Journal Of Animal Research \& Veterinary Science | ISSN: 2639-3751

Journal Of Aquaculture \& Fisheries | ISSN: 2576-5523

Journal Of Atmospheric \& Earth Sciences | ISSN: 2689-8780

Journal Of Biotech Research \& Biochemistry

Journal Of Brain \& Neuroscience Research

Journal Of Cancer Biology \& Treatment | ISSN: 2470-7546

Journal Of Cardiology Study \& Research | ISSN: 2640-768X

Journal Of Cell Biology \& Cell Metabolism | ISSN: 2381-1943

Journal Of Clinical Dermatology \& Therapy | ISSN: 2378-8771

Journal Of Clinical Immunology \& Immunotherapy | ISSN: 2378-8844

Journal Of Clinical Studies \& Medical Case Reports | ISSN: 2378-8801

Journal Of Community Medicine \& Public Health Care | ISSN: 2381-1978

Journal Of Cytology \& Tissue Biology | ISSN: 2378-9107

Journal Of Dairy Research \& Technology | ISSN: 2688-9315

Journal Of Dentistry Oral Health \& Cosmesis | ISSN: 2473-6783

Journal Of Diabetes \& Metabolic Disorders | ISSN: 2381-201X

Journal Of Emergency Medicine Trauma \& Surgical Care | ISSN: 2378-8798

Journal Of Environmental Science Current Research | ISSN: 2643-5020

Journal Of Food Science \& Nutrition | ISSN: 2470-1076

Journal Of Forensic Legal \& Investigative Sciences | ISSN: 2473-733X

Journal Of Gastroenterology \& Hepatology Research | ISSN: 2574-2566
Journal Of Genetics \& Genomic Sciences | ISSN: 2574-2485

Journal Of Gerontology \& Geriatric Medicine | ISSN: 2381-8662

Journal Of Hematology Blood Transfusion \& Disorders | ISSN: 2572-2999

Journal Of Hospice \& Palliative Medical Care

Journal Of Human Endocrinology | ISSN: 2572-9640

Journal Of Infectious \& Non Infectious Diseases | ISSN: 2381-8654

Journal Of Internal Medicine \& Primary Healthcare | ISSN: 2574-2493

Journal Of Light \& Laser Current Trends

Journal Of Medicine Study \& Research | ISSN: 2639-5657

Journal Of Modern Chemical Sciences

Journal Of Nanotechnology Nanomedicine \& Nanobiotechnology | ISSN: 2381-2044

Journal Of Neonatology \& Clinical Pediatrics | ISSN: 2378-878X

Journal Of Nephrology \& Renal Therapy | ISSN: 2473-7313

Journal Of Non Invasive Vascular Investigation | ISSN: 2572-7400

Journal Of Nuclear Medicine Radiology \& Radiation Therapy | ISSN: 2572-7419

Journal Of Obesity \& Weight Loss | ISSN: 2473-7372

Journal Of Ophthalmology \& Clinical Research | ISSN: 2378-8887

Journal Of Orthopedic Research \& Physiotherapy | ISSN: 2381-2052

Journal Of Otolaryngology Head \& Neck Surgery | ISSN: 2573-010X

Journal Of Pathology Clinical \& Medical Research

Journal Of Pharmacology Pharmaceutics \& Pharmacovigilance | ISSN: 2639-5649

Journal Of Physical Medicine Rehabilitation \& Disabilities | ISSN: 2381-8670

Journal Of Plant Science Current Research | ISSN: 2639-3743

Journal Of Practical \& Professional Nursing | ISSN: 2639-5681

Journal Of Protein Research \& Bioinformatics

Journal Of Psychiatry Depression \& Anxiety | ISSN: 2573-0150

Journal Of Pulmonary Medicine \& Respiratory Research | ISSN: 2573-0177

Journal Of Reproductive Medicine Gynaecology \& Obstetrics | ISSN: 2574-2574

Journal Of Stem Cells Research Development \& Therapy | ISSN: 2381-2060

Journal Of Surgery Current Trends \& Innovations | ISSN: 2578-7284

Journal Of Toxicology Current Research | ISSN: 2639-3735

Journal Of Translational Science And Research

Journal Of Vaccines Research \& Vaccination | ISSN: 2573-0193

Journal Of Virology \& Antivirals

Sports Medicine And Injury Care Journal | ISSN: 2689-8829

Trends In Anatomy \& Physiology | ISSN: 2640-7752

Submit Your Manuscript: https://www.heraldopenaccess.us/submit-manuscript 